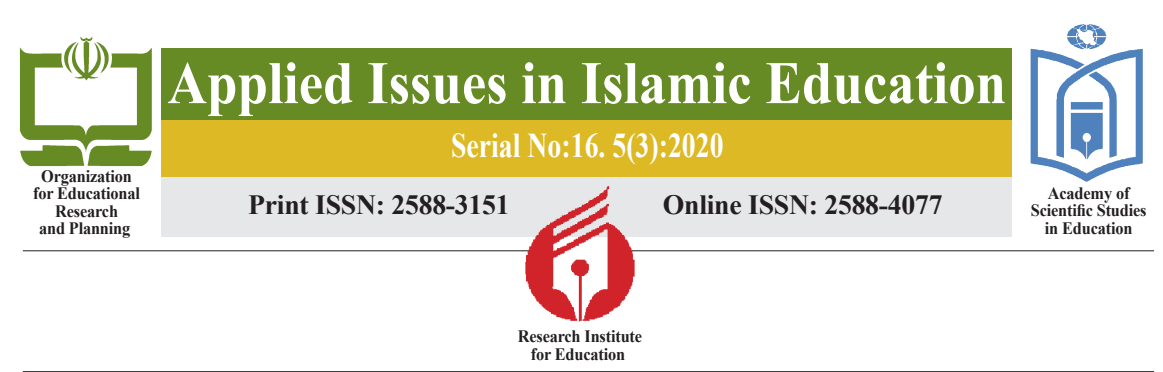

\title{
The Model of the Structural Relationships between Religious Identity and Social Capital with the Quality of Life: the Mediating Role of Self-Differentiation
}

\author{
Esmail Soleimani $^{1}$, Mahdiyeh Sarshar ${ }^{2}$, Seyyed Javad Mir-Mahdi-Pour Koohkamar ${ }^{3}$
}

- Objective: This study aims to investigate the structural model of relationships between religious identity and social capital with the quality of life through the mediating role of self-differentiation among the students of Urmia University.

- Method: In order to do the research, from among the students of Urmia University (N:17568), 350 students were selected by the cluster random sampling method, and they answered the Khoshavi's Religious Identity Questionnaire (2011), the Questionnaire of Christaan Grootaert et al. on Social Capital (2003), and the questionnaire for the Quality of Life of the World Health Organization (1989), and the Scale Scoring of Differentiation of Self Inventory (Skowron and Friedlander, 1998), which all of them have been localized. The path analysis method based on software LISREL (V. 8.8) and SPSS Amos was used to analyze the results.

Finding: The findings showed that the model designed based on research data has a proper fitness, and there was a positive and significant relationship between direct paths, social capital, religious identity, and differentiation of self, with the quality of life. Furthermore, there was a positive and significant relationship between indirect paths, social capital, and religious identity, with the quality of life through differentiation of self.

- Conclusion: According to these findings, it can be concluded that differentiation of self, as a mediating factor, well regulates the relationship between social capital and religious identity with the quality of life.

Keywords: the quality of life, differentiation of self(self-differentiation), religious identity, social capital.

Citation: Soleimani,E.,\& Sarshar,M.,\& Mir-Mahdi-Pour Koohkamar,S. (2020). The Model of the Structural Relationships between Religious Identity and Social Capital with the Quality of Life the Mediating Role of Self-Differentiation. Applied Issues in Islamic Education, 5(3): 61-82.

1. Corresponding Author: Associate Professor, the Psychology Department, Urmia University, Urmia, Iran.

E-mail: E.soleimani@urmia.ac.ir. (iD) 0000-0002-7204-1229

2. MA, the Psychology Department, Urmia University, Urmia, Iran.

E-mail: m.sarshar95@gmail.com. (iD 0000-0002-7142-4236

3. Assistant Professor, the Mā'rif Department, Urmia University, Urmia, Iran.

E-mail: sj.mirmehdipour@urmia.ac.ir. (D) 0000-0003-0582-4378 


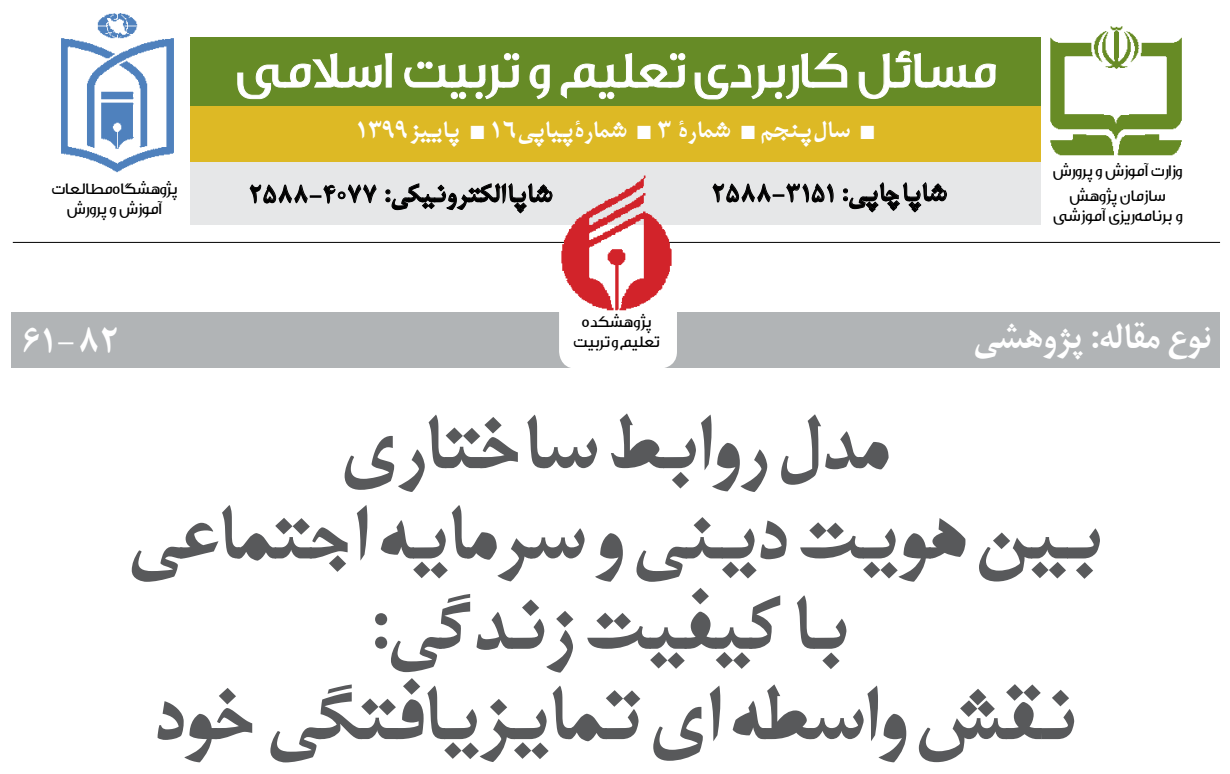

سيد جواد ميرمهدى يور كوه كمر

مهديه سرشار

اسماعيل سليمانى

ه هدف: هزوهش حاضر با هدف بررسى رابطه بين هويت دينى و سرمايه اجتماعى با كيفيت

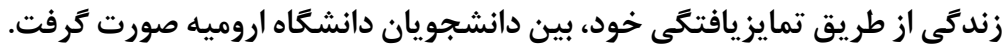

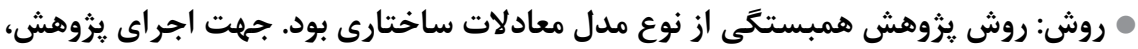

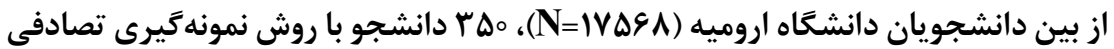

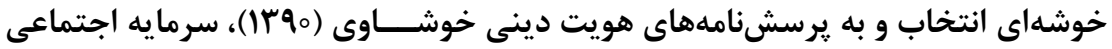

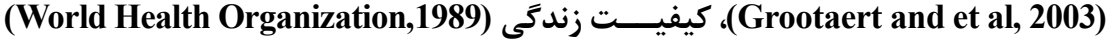

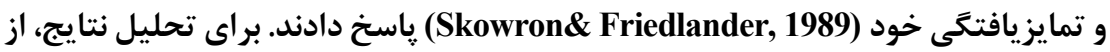
روش تحليل مسير براساس نرم افزار (LISREL V.8.8) و Amos

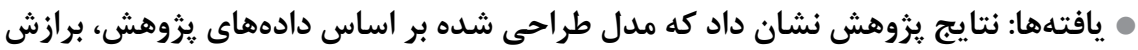

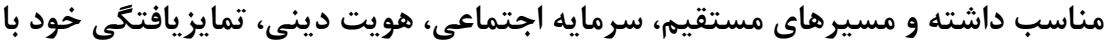

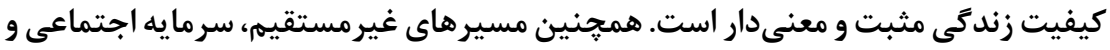

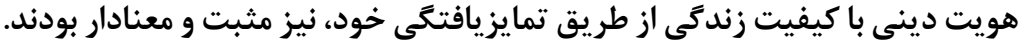

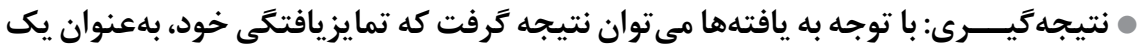

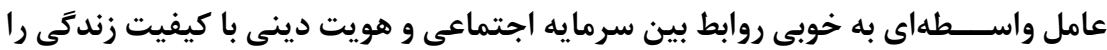
تنظيم مى كند.

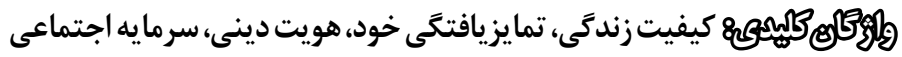
Email: E.soleimani@urmia.ac.ir (iD 0000-0002-7204-1229 


\section{مقدمه}

مفهوم كيفيت زندگى ' از منظر توسعه اقتصادى اجتماعى و فرهنگى گسترش يافته و يكى ســاختار جُندبُعدى اســت كه مطالعات مختلف جنبههاى مختلف آن را در نظر مى گيرد (Nowak, Boz’ek, \& Blukacz،2019). كيفيت زندگى ســاختارى گســــرده و شامل جند بعد است، از جمله جسمى، روانى، اجتماعى و محيطى.كيفيت زندكى متفاوت از ساير معيارهايى از جمله علائم افسردگى، عملكرد اجتماعى و شغلى است كه معمولاً

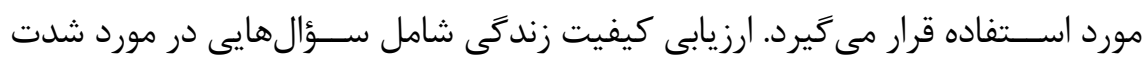

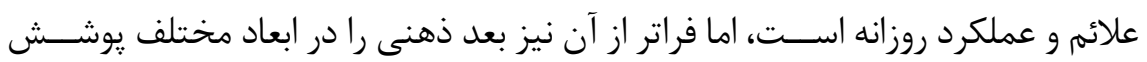
مى دهـــ. (Lex, Ginsburg, F.sitzmann, Grayhack et al, 2018) كيفيــت زندخَّـى بنابر تعريـف (World Health Organization ,1998)، به منزله ادراك يك شخص از موقعيتش

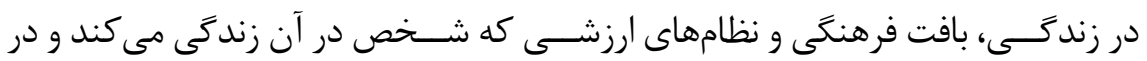
ييوند با اهداف، انتظارات، معيارها و علايقش قرار دارد، تعريف مىشود (مهدى، هوس ا). بر اســاس اين تعريف جامع، كيفيت زندكى بهعنوان رضايت كلى از خود در زمينههاى مختلف زندگى، از جمله بهزيســتى جســمى، روابط اجتماعى، فعاليتهاى اجتماعى و Hunt, Zahid, Ennis, Michalak) تفريحى، و تحقق شخصى تعريف و مفهومسازى مى

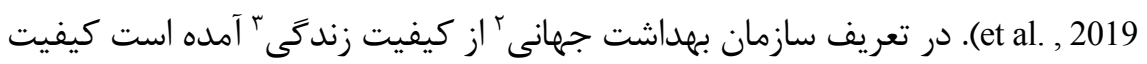
زندكى مفهومىفراكير است كه از سلامت فيزيكى، رشد شخصى، حالات روانشناختى،

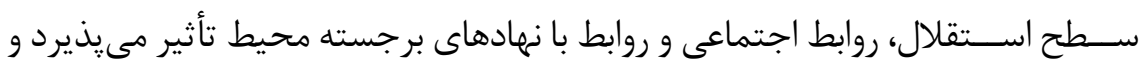
بر برداشت فرد مبتنى اسـت. در واقع كيفيت زندگى گسترهاى است در برگيرنده ابعاد عينى و ذهنى كه با يكديگر تعامـلـل دارند. در نتيجه كيفيت زندگى، مفهومى يبيجيده و

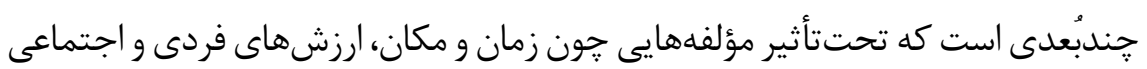
قرار دارد، و از اينرو معانى گوناگونى براى افراد و گروههاى مختلف بر آن مترتب اســت. برخى آن را بهعنوان قابليت زيست يذيرى يك ناحيه، برخى ديخر بهعنواناندازهاى براى ميزان جذابيت و برخى براى رفاه عمومى، بهزيستى اجتماعى، شاد كامى، رضايتمندى و مواردى از اين دست تعبير كردهاند (اسماعيلى، وجسا ).

1. Quality of Life

2. world Health Organization

3. quality of life 
يكسى از عوامل و متغيرهايى كه بر كيفيت زندگى به خصــــــ درص حالت فردى اثر

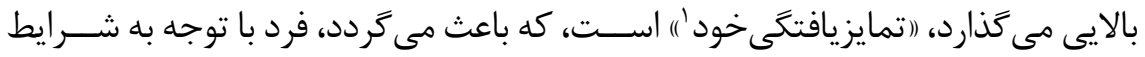

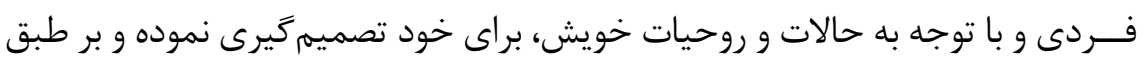

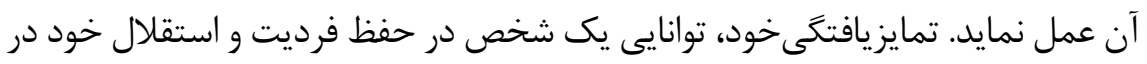

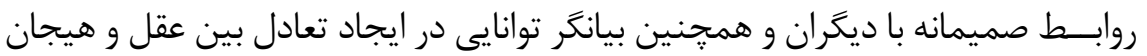

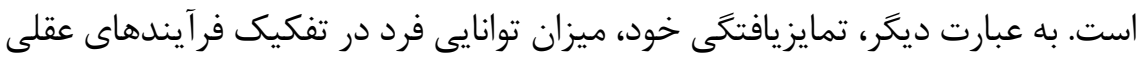

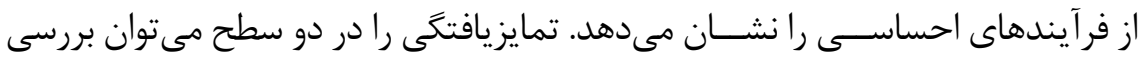

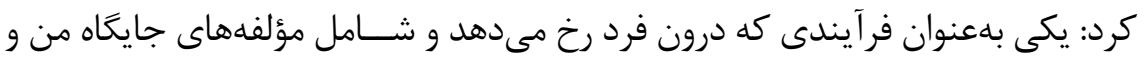

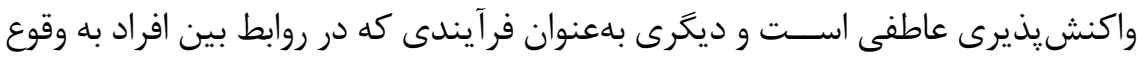

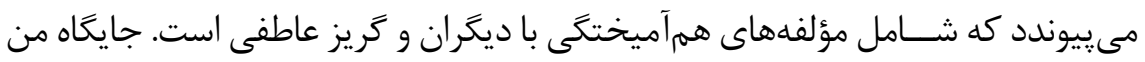

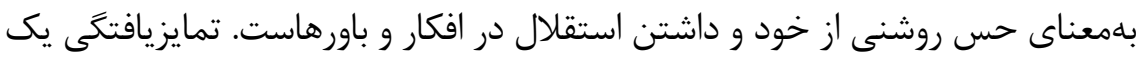

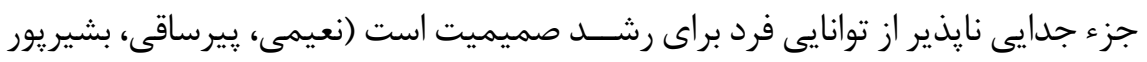

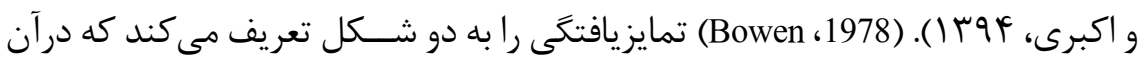

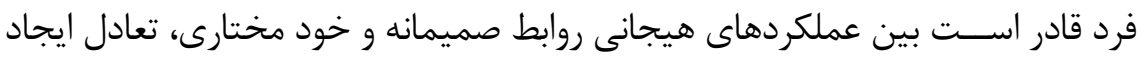

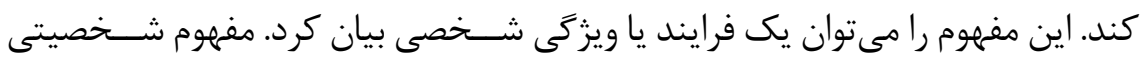

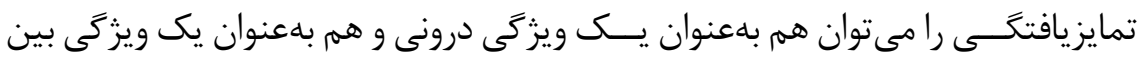

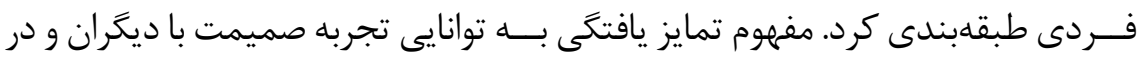
عين حال استقلال از ديخران اشاره دارد (Zeegers, Colonnesi, Stams \& Meins،2017).

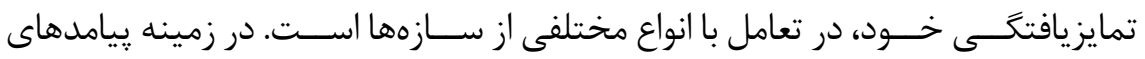

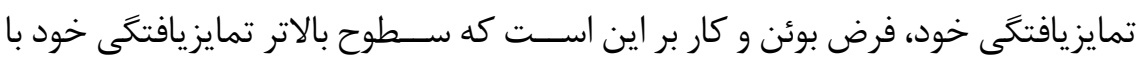

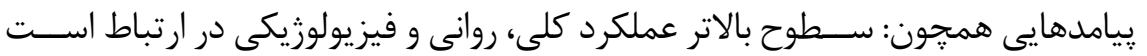

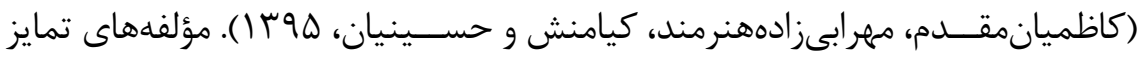

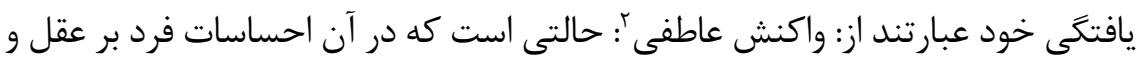

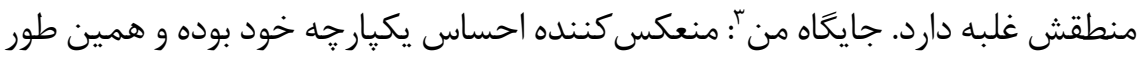

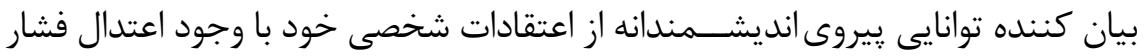


از سوى ديخران اســت. جدايى عاطفى ': بر طبق نظر (Bowen،1978) جدايى عاطفى با روش افراد در جدايى خودشان از گذشته بهمنظور شروع زندگى در نسل حاضر سر و كار دارد. هم جوشى با ديگران '؛ منعكس كننده در گيرى زياد با افراد مهلم زندگى و وابستخى

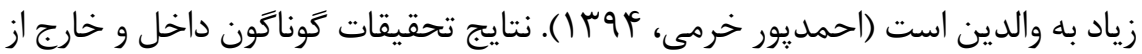
كشور نيز وجود رابطه بين تمايزيافتخى با كيفيت زندكى، سرمايه اجتماعى و هويت دينى رادر افــراد كم و بيش مورد تأييد قرار داده اسـت (Likcani، 2013 Gabelman، 2012؛

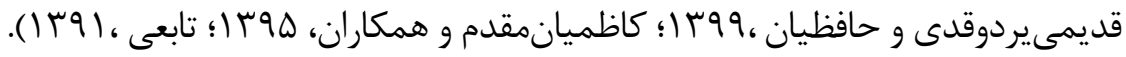

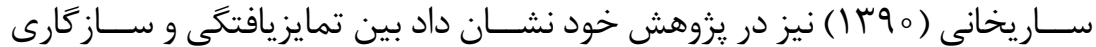

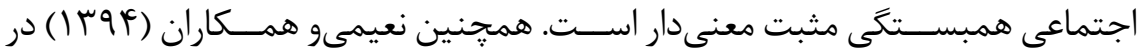
يزوهشـــى ضمن بررسى نقش مؤلفههاى سلامت خانواده اصلى و ابعاد تمايزيافتخى خود در ييشبينى رغبت به ازدواج در دانشجويان، نشان دادند كه مؤلفههاى سلامت خانواده اصلى و تمايزيافتخى خود با ابعاد رغبت به ازدواج در دانشــجويان رابطه داشته و بهطور معنادارى آن را ييشبينى مئى كنند. يكىديگر از از عواملى كه در عصر حاضر مىتواند بر كيفيت زندگى دانشـــويان اثر بالايى دارد، (هويت دينى ")، افراد است. آنجه بهعنوان هويت انسانى از آن ياد ميىشود، تا حدود زيادى تحت تأثير باورهاو اعتقاداتى است كه مىتوانند بهعنوان هويت دينى شناخته شوند. هويت دينى يعنى اتكاى فرد به يك نظام يا يايگاه اعتقادى كه بر جهت گيرى فرد در زمينههاى مختلــف تأثير مى گذارد و در واقع مى توان كفت هويت مذهبى فلســـهـ زندكى و حيات يك فرد را تشكيل مى دهد (خسرو شاهى و جوادى حسين آبادى، هوس ا ). در يزوهشهاى انجام شده در حوزه دين، ديدگًاها و نظريههاى فلسفى، جامعهشناختى

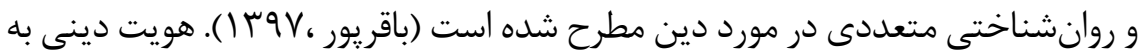
دليل اهميت ماهوى و محتوايىاش در جامعه ايران، يكى از مهممترين ابعاد هويتى اســت كه نقش تعيين كنندهاى در هويت يابى افراد جامعه ايفا مى كند و در تعامل با شــرايط اجتماعى و طى مراحل متفاوت جرخه زندگى تنوع مى يذيرد. در جهان امروزى، در يرتو جهانى شدن و افزايش جشهم گير رسانههاى ارتباطى فرا سرزمينى، توجه بــه دين و هويت 
دينى اهميت دو جندانى ييدا كرده است. زيرا برخلاف دوران مدرن اوليه كه تصور مىرفت دين از زندگى اجتماعى رخت برمىبندد و تأثيرش به قلمروى خصوصى محدود مى بـشود

امروزه، در دوران مدرن ثانويه و با ظهور و گسترش همه جايى جنبشهاى دينى تزِ ضد دنيوى شدن مطرح شده است كه بامعناى نفوذ و تأثير جشمثير دين در تمام قلمروهاى

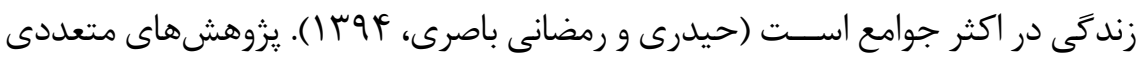

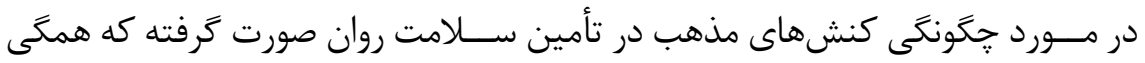
بيانكر اين اســت كه مذهب و گرايشهاى مذهبى ســبب كاهش اضطراب، خودكشى، مصرف مواد، بزهكارى و افسردكى مىشوند و سبب افزايش رضايت از زندكى و ساز گارى اجتماعى مىشود (Mccullough, Pargament, K, \& Thorensen, 2009 وكيميايى، خادميان

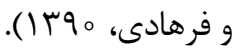
اكثر تحقيقات نيز نشان داده كهبخش زيادى از كيفيت زندى تحت تأثير هويت دينى وديندارى است .(Rajagopal, Mackenzie, Bailey \& Lavizzo-Mourey, 2008; Galanter \& Siegel, 2002; Bandura, 2009) جنانكه، يافتهاى تحقيق احمدى، ميرفردى و ابتكارى (سوس|)، نشــان داد بين هويت دينــى و كيفيت زندگى رابطه مثبــت و معنادارى وجود دارد. خواجــــه نورى، رياحى و مســاوات (هوس|) در مطالعه خود به اين نتيجه رسيدند، تقويت عوامل مذهبى، باورها،

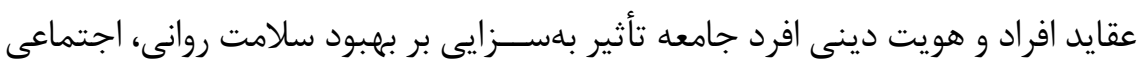

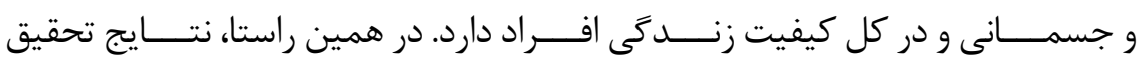

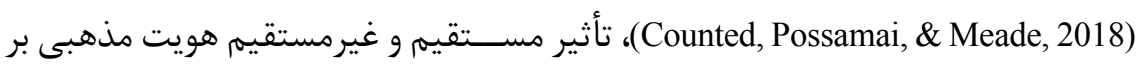
كيفيت زندگى را مورد تأييد قرار داده اســت. يافتههاى تحقيق (Lim and Yi, 2009) نيز مبين تأثير مثبت ديندارى و معنويت بر ريامدهاى كيفيت زندكى مى بـاشد. همجنين يكى ديخر از متغيرهايى كه بهعنوان متغير مستقل مورد بررسى قرار زرفته

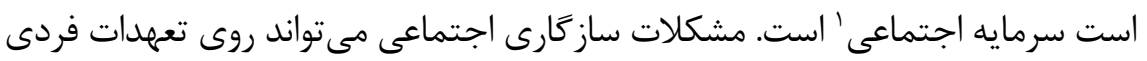
و اجتماعى تأثير بخذارد و موجب مشـــكلاتى در ســلامت فردى و اجتماعى شود. زمانى اجى كه روابط اجتماعى گسســــه شــود، توانايى تنظيهم و مديريت رفتـــار نيز از بين مىرود. كمبود يا نبود روابط اجتماعى كه در نتيجه ســاز ₹ارى اجتماعى نامطلوب رخ مى ردهد، مى تواند روى انخيزه و سلامت روان فرد تأثير منفى بخذارد (George \& Ukpong, 2012). 
ســازكَارى اجتماعى جوانان نيز به مثابئ مهممترين نشانهُ سلامت روان، از مباحثى است كه در جُند دهؤ اخير توجه بســيارى را به خود جلب كرده اســت. شايد بتوان كفت كه

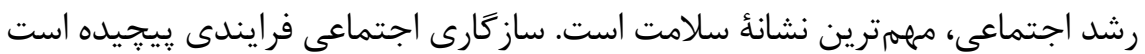
و از تعامل فرد با محيط نشأت مى گيرد زيرا فرد رفتار خود را متناسب با فرهنَ موجود در جامعـــ، مقررات، محدوديتها، معيارها وآداب و رســـوم اجتماعى هماهنكى مى كند (Alofinto 2008). و در صـــورت وجـود تــــوافقى منطقى بين آنجه فرد راجع به خود

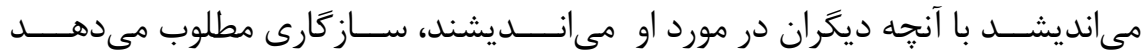
(Kwak, Chung, Xu and Eun-Jung, 2010 , Baranci \& vidal, 2007) يـــ جامعه در بر زيرنده نهادها، روابط، نخرشها و ارزشهايى اســت كه اصولاً حاكم بر تعاملات بين افراد آن جامعه است و به توسعه اقتصادى و اجتماعى آن كـمك ميى كـند. در واقع، سرمايه اجتماعى شامل قواعد و ارزشهاى مشترك براى رفتارهاى اجتماعى مطرح در روابط شخصى و همجنين شامل اعتماد و حس مشترك از مسئوليت مدنى است كه جامعه را تبديل به جيزى فراتر از يك مجموعه از افراد مى كند (باديندهش، كوس ا ). عوامل ساخت سرمايه اجتماعى را به جهار دسته تقسيم كردهاند: عوامل نهادى، عوامل خودجوش؛ عوامل بيرونى و عوامل طبيعى. از طرف ديخر ابعاد سرمايه اجتماعى در يك دستهبندى، به سه بُعد: ساختارى، شــناختى و ارتباطى تقسيم مى شود و در يكى تقسيمبندى ديكر

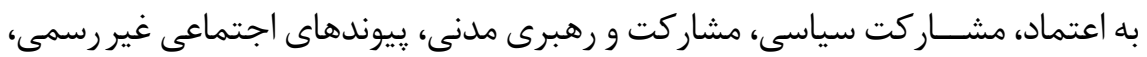
بخشش و روحيه داوطلبى، مشاركت مذهبى، عدالت در مشاركت مدنى، و تنوع معاشرتها

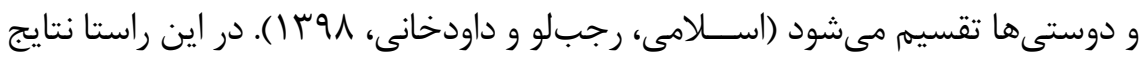
تحقيقات انجام شــده زير، حاكى از وجود رابطه بين دو سازه سرمايه اجتماعى، كيفيت

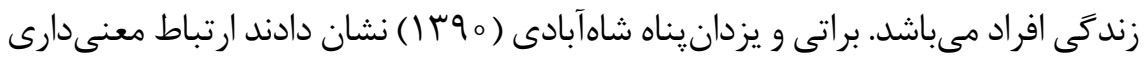

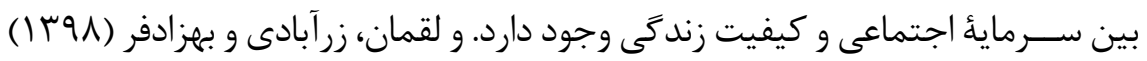
نتيجه گرفتند، ارتباط معنى دار ميان ابعاد متغير سرمايةٔ اجتماعى و كيفيت زندگى وجود دارد. نتايــج يزوهش مبين آن بود كه از طريق افزايــش اعتماد بهعنوان تأثير حذارترين

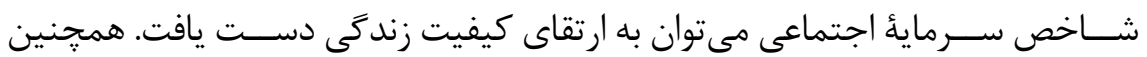

Cristina Viana Campos, Marques Borges, Rodrigues Leles, Dutra Lucas, et al (2013)

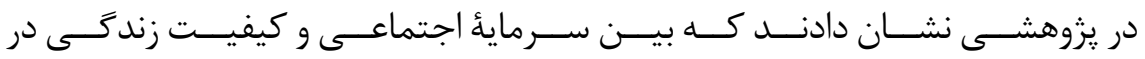


دانشآموزان نوجـــوان برزيلى رابطة مثبت و معنى دار وجـــود دارد. و يافتههاى تحقيق نيز حاكى از اين اســت كه شــاخصهاى (Lucumí, Gomez, Brownson \& Parra,2014)

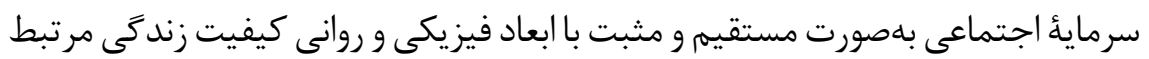
با سلامتى مرتبط بوده است. با عنايت به بررسى و اهتمام به مسائل مهرم تعليم و تربيت در عصر حاضر و هجمههاي

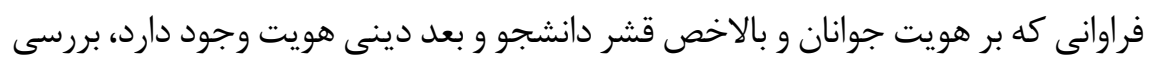
هويتدينى در جمهورى اسلامىايران، با توجه به فضاى مذهبى و ماهيت و اهداف نظ نظام

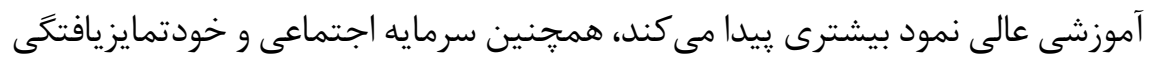

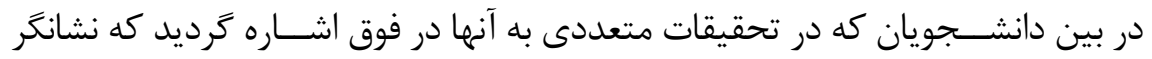

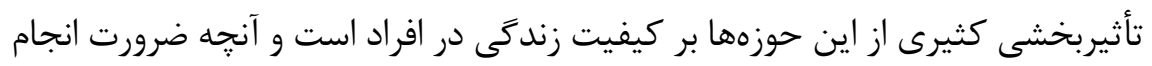

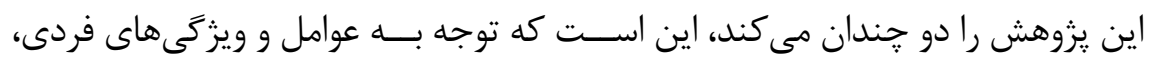

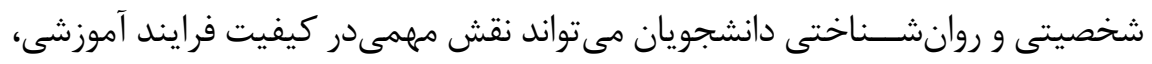

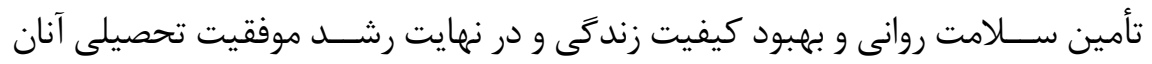

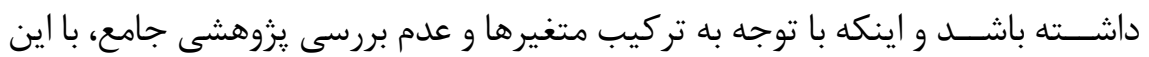

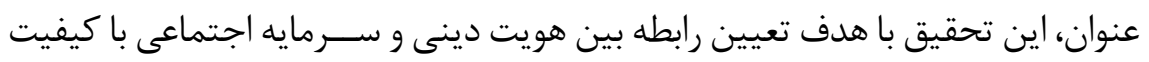

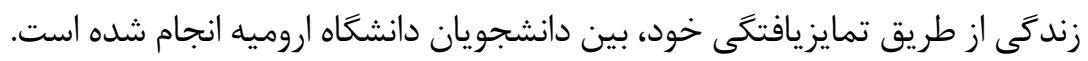

\section{روش}

روش تحيق يزوهش، جزء يزوهش هاى كاربردى و از نظر اجراء بر اساس مدل ارتباطى

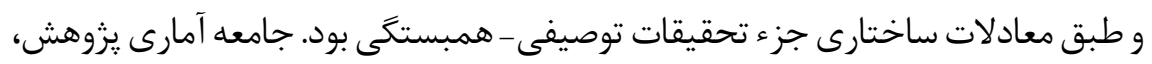

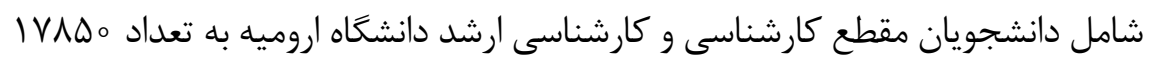

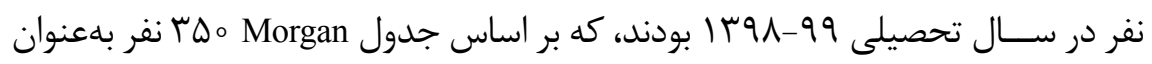

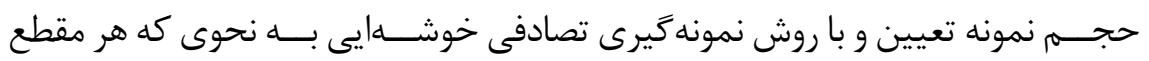

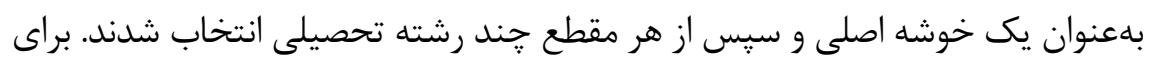
كردآورى دادها از ابزارهاى ذيل استفاده شده است:

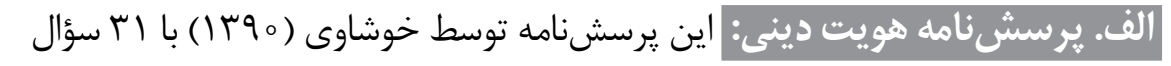

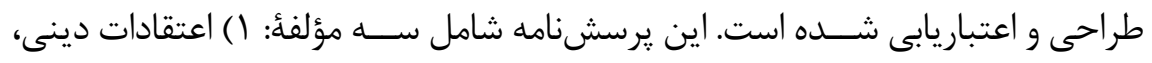


ץ) عواطف و احساســات دينى و ؟) انجام رفتارهاى دينى اســت، كه ســـؤال هاى 1-9

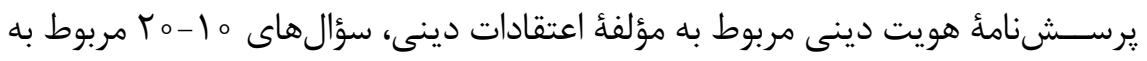

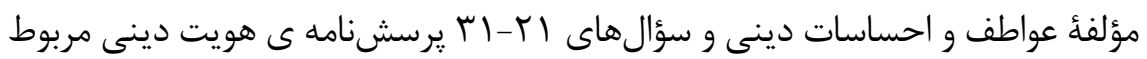
به مؤلفهُ انجام رفتارهاى دينى اســت. زيربناى نظرى اين :رسشنامه براساس مطالعات انجام گرفته در زمينه ى هويت دينى و همجنين مقياسهاى دين اسلام است و در نهايت روايى صورى و محتوايى ســؤال هاى يرســشنامه مورد تأييد اساتيد قرار گرفت. نمرات براى هريك از ســؤالات از ا تا ه در تغيير مىباشد. نمرات بين اس تا اله نشانگر سطح

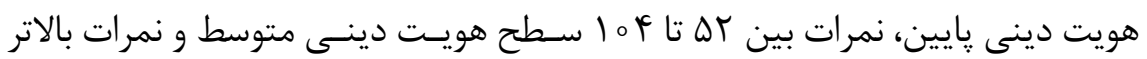

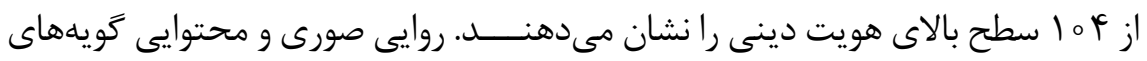
يرسشنامه در تحقيقات قبلى مورد تأييد اساتيد فن قرار زرفته است (شامانى، واحدى و

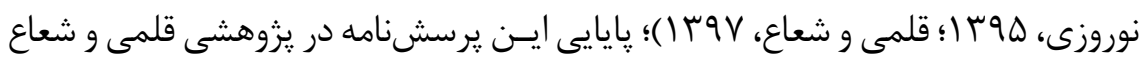

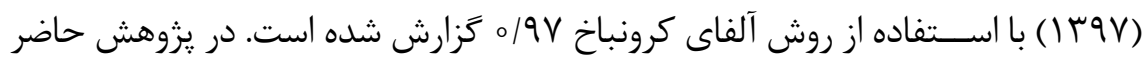
يايايى يرسشنامه حاضر با آلفاى كرونباخ بهدست آمد كه براى مؤلفههاى مورد بررسى به

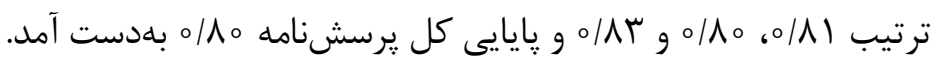

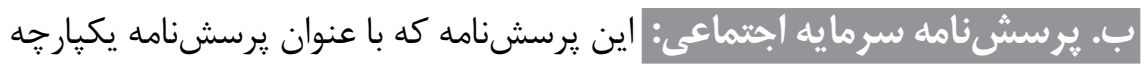
و و با علامت اختصارى 'Grootaert, Narayan, Jones, Woolcock, 2003) داده مىشـــود؛ از بانكـ بين المللى بازسازى و توســعه، بانك جهانى واشينگتن دى.سى اســـتخراج شده است. از اين يرسشنامه در كشـــورهاى آلبانى (اروياى شرقى) و نيجريه

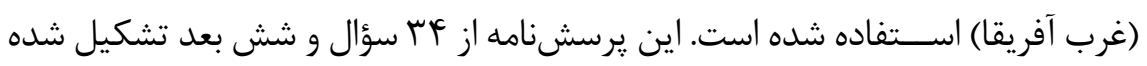
كه شامل: () عضويت در گروهها و شبكهها سؤالات ا تا ما؛ Y) اعتماد و اتحاد سؤالات

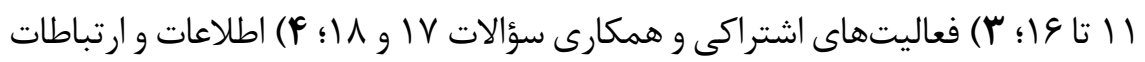

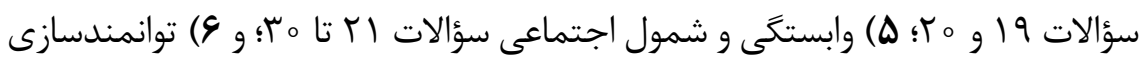

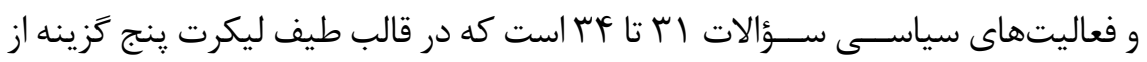

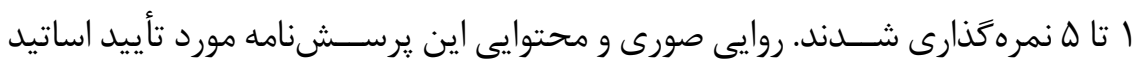

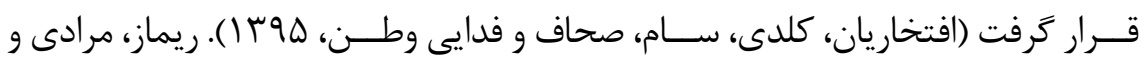

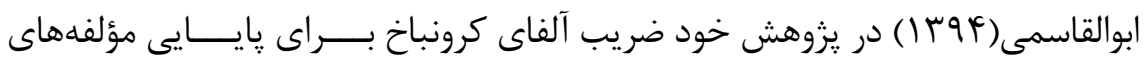




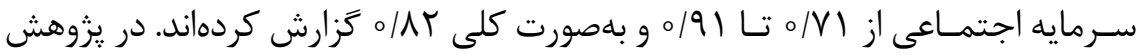
حاضر يايايى : يرسـشـنامه حاضر با آلفاى كرونباخ بهدست امد كه براى مؤلفههاى مورد

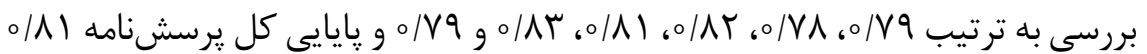
بلمدست آمد.

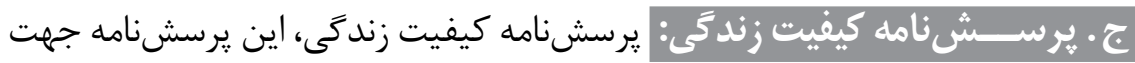

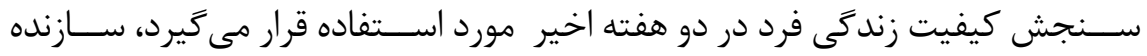
آن سازمان بهداشـت جهانى با همكارى ها مركز بينالمللى سال 1919 است، تعداد

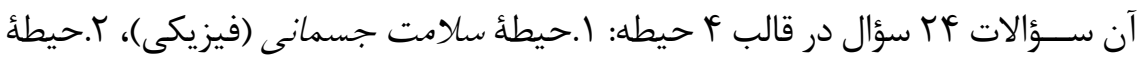
روانشــاختى، ب. حيطهُ روابط اجتماعى و أ.حيطهُ محيط زندكى؛ كه دو سؤال اول به هيج يك از حيطهها تعلق ندارد و وضعيت ســلامت و كيفيت زندكى را به شــكل كلى لى مورد ارزيابى قرار مىدهند، لازم به ذكر است كه سؤالهاى

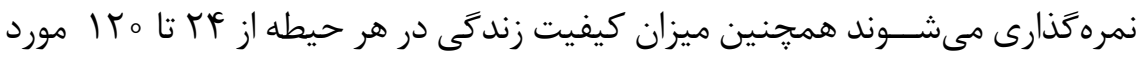
تفســير قرار خواهد گرفت. در نتايج ززارش شده توسط گروه سازندگان مقياس كيفيت زندكَى ســازمان بهداشــت جهانى كه در ها هـ مركز بينالمللى اين ســـازمان انجام شده،

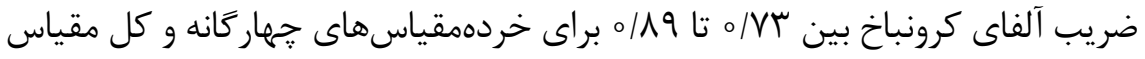

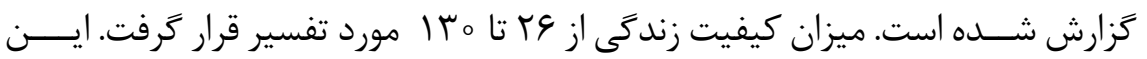
يرسشنامه در بـــيش از F م كـشور جهان، ترجمه و مورد اعتبارسنجى واقع شده است و Min, Kim, Lee ،2006)

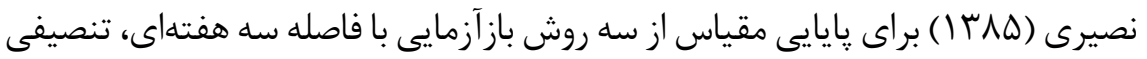

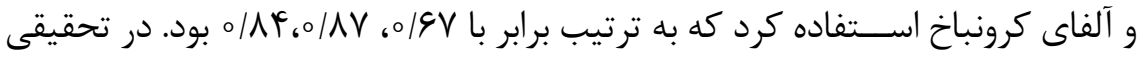

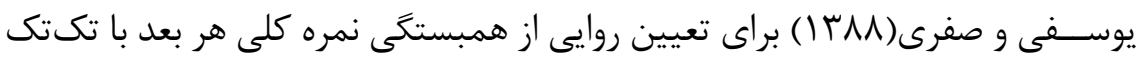
سؤالهاى تشكيلدهنده آن بعد استفاده شد. دامنه ضريبهاى همبستخى بهدست آمده از هأ/ه تاسم/ه بود و همه ضريبها در سطح | ه/معنادار بودند. هر گويه نيز بيشترين

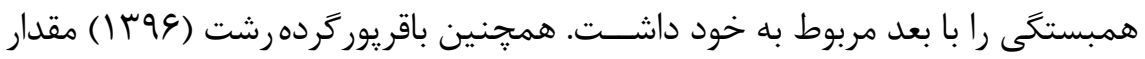

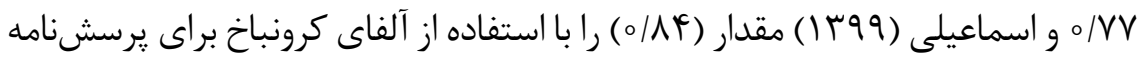

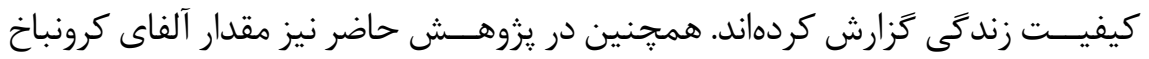


د. يو سشى نامه تمايز يافتكًى خود: توسط (Skowron \& Friedlander, 1998) تدوين و طراحى شده است. يرسشنامه تمايز يافتتى خود داراى أf سؤال و شامل F خردهمقياس است:

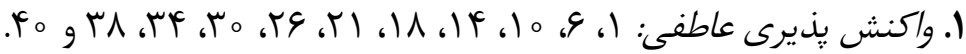

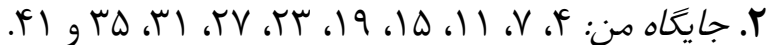

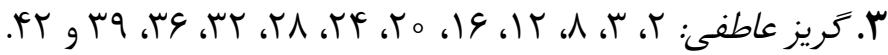

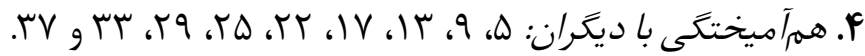
آيتمهاى مرتبط با اين خردهمقياس نشاندهنده ترس از روابط صميمانه، رفتارهاى دفاعى مانند عملكرد بيش از حد، فاصله گيرى، يا انكار مى باشـــد. سرانجام همآميختخى

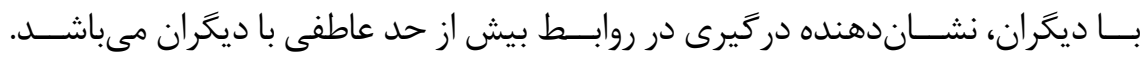

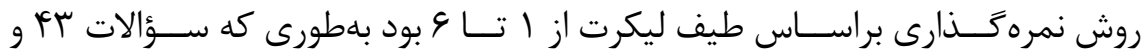

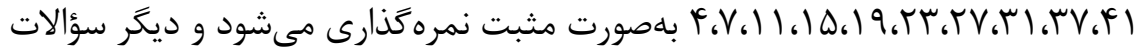
به شكل معكوس نمره گذارى شدند (محمدى و اصغرى ابراهيمآباد، 99 ا ). قابليت اعتماد يا پايايى يك ابزار عبارت اســت از درجه ثبات آن دراندازهگيرى هر آنجهاندازه مى گيرد يعنى اينكه ابزاراندازهگيرى در شرايط يكسان تا جهاندازه نتايج يكسانى بهدست مى بهد. Skowron \& Friedlander

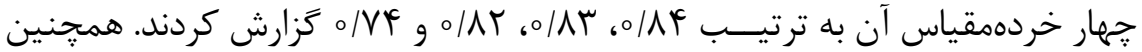
براى تعيين روايى عاملى از تحليل عاملى اكتشــافى و تحليل عاملى تأييدى مورد تأييد

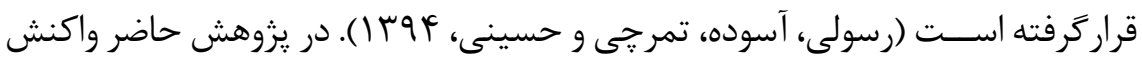

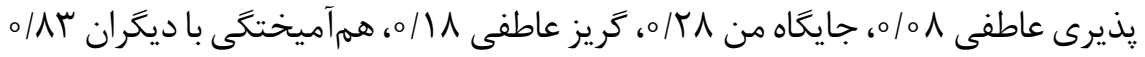

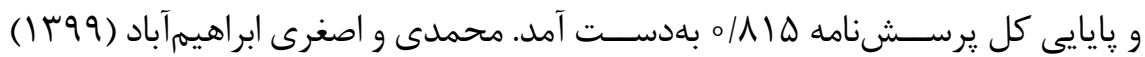

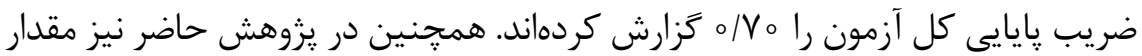

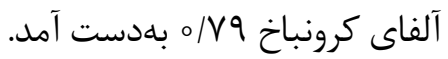
جهت تجزيه و تحليل دادهها از نرم افزار (Lisrel V. 8.8) و Amos و آزمون همبستخى لهـ ״يرسون و تحليل مسير و معادلات ساختارى استفاده شد. 


\section{يافتهها}

نتايج مطالعه نشان داد كه ميانكَين و انحراف استاندارد سنى شركت كنندكان مطالعه

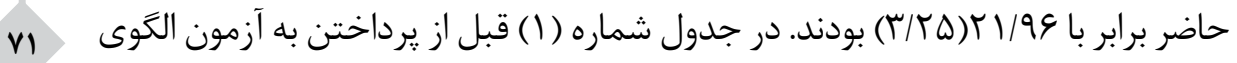

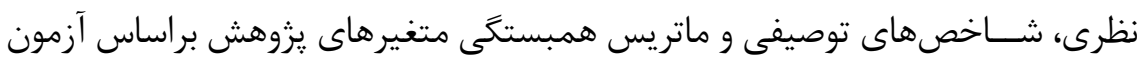

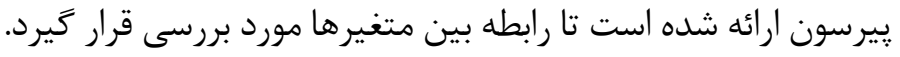

جدولا. ماتريس همبستكى، ميانكين و انحراف استاندارد متغيرهاى يزوهش

\begin{tabular}{|c|c|c|c|c|c|}
\hline r & $r$ & $r$ & 1 & $(\mathrm{SD}) \mathrm{M}$ & متغير \\
\hline & & & 1 & $(11 / 09) 109 / 41$ & هويت دينى \\
\hline & & 1 & 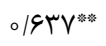 & $(9 / T \Gamma) 9 / / 11$ & سرمايه اجتماعى \\
\hline & 1 & $0 / \Delta S V^{E s}$ & o|Qr| & $(V / \circ T) V \Delta / / 9$ & كيفيت زندكى \\
\hline 1 & $0 / 90 r^{\prime \prime a n}$ & 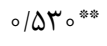 & $0 / 919^{\text {the }}$ & $(\mid r / \Lambda F) \| / r / \mu q$ & تمايزيافتكى خود \\
\hline
\end{tabular}

نتايج در جدول ا نشــان دادند كه بين متغيرهاى يزوهش در ســطح ا درصد و با

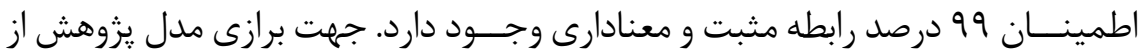
شاخصهاى برازش استفاده شد.

جدول r. مقايسه شاخصهاى برازندكى مدل بيشنههادى و اصلاحشده

\begin{tabular}{|c|c|c|c|c|c|c|c|c|}
\hline RMSEA & PNFI & CFI & TLI & IFI & AGFI & GFI & CMIN/DF & شاخصها \\
\hline$>0 / 0 \Lambda$ & $>0 / \Delta_{0}$ & $>0 / 90$ & $>0 / 90$ & $>0 / 90$ & $>0 / \Lambda_{0}$ & $>0 / 90$ & ا تاه & بازمى قابلقبول \\
\hline \% Vq &.$/ 09$ & $0 / 19$ & ०/A & $\circ / \Lambda \Lambda$ & o/AF & $\circ / \Lambda \Lambda$ & $r / 91$ & مدل بيشنهادى اوليه \\
\hline$\% 1090$ & $0 / 9 \pi$ & $0 / 94$ & $0 / 91$ & . 94 & $0 / \Lambda 9$ & .91 & $r / 09$ & مدل اصلاحشده نهايى \\
\hline
\end{tabular}

با توجه به نتايج مندرج در جدول r، هر جند كه در مدل يیشنهادى اوليه سه شاخص

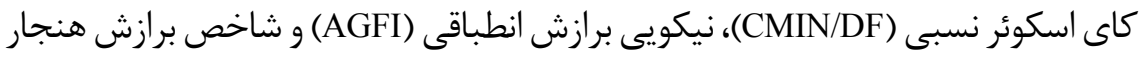

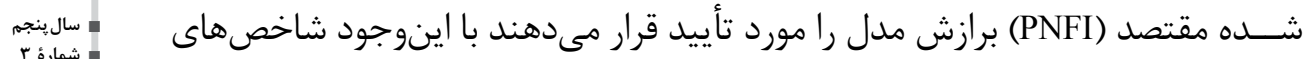

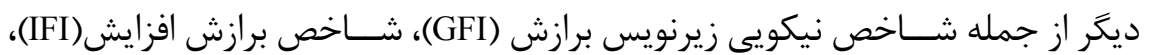


شــاخص برازندگى توكر - لويس (TLI)، شاخص برازش تطبيقى (CFI) و جذر ميانخين

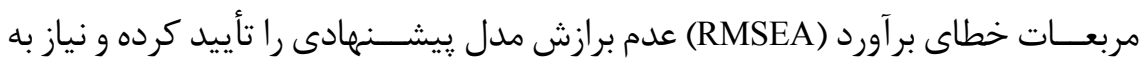
اصلاح مدل را نشــان مى دهند، ازاينرو بهمنظور بهبود مدل، دو اصلاح همبسته كردن

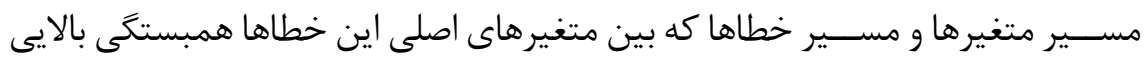
وجود داشت از بين ززينههاى ييشنهادى نرمافزار AMOS انتخاب و همبسته شدند. بعد از اعمال تغييرات و اصلاح، مدل مجدداً مورد آزمون قرار رَفت تمامىشاخصهاى برازش برد مدل اصلاحشــده برازش مدل اصلاحى را تأييد كردند. مدل يزوهش به روش بيشـــينه احتمال با نرمافزار AMOS طراحى و سنجيده شد.

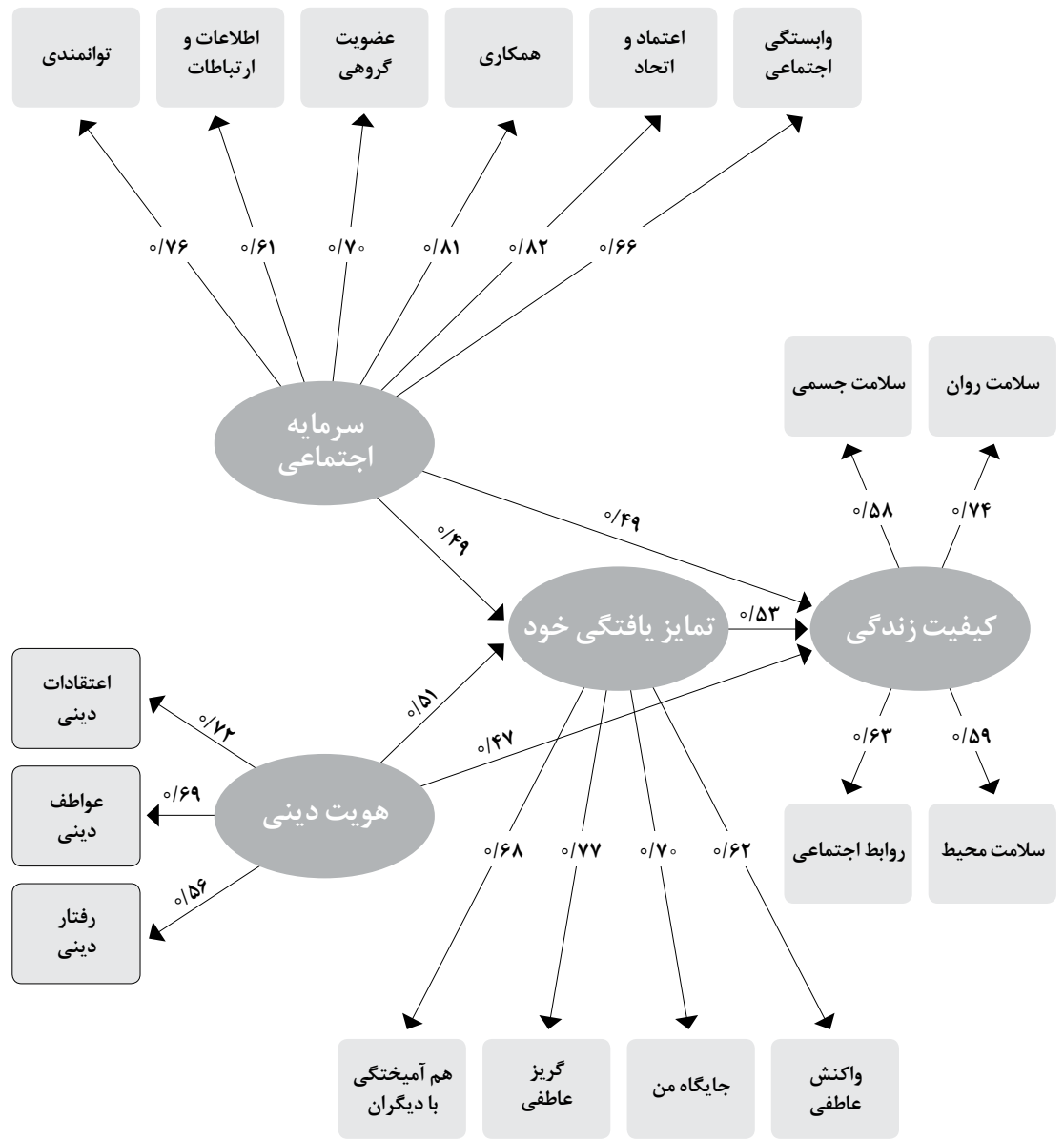

شكلا. مدل اصلاح شده نهايى به همر اه ضرايب استاندارد مسيرها 
ضرايب اســتاندارد مسيرها در شكل ا حاكى از آن است كه مسير سرمايه اجتماعى

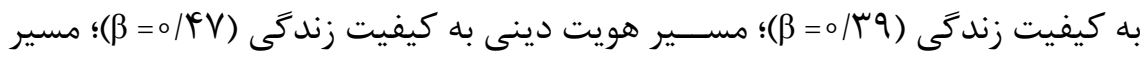

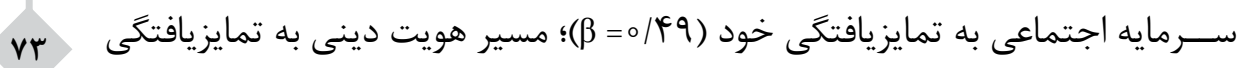
خود ( (D/ه= معنى دار است. همجنين، بامنظور بررسى معنى دارى روابط واسطهاى از آزمون بوت استراب نرمافزار AMOS استفاده شده كه نتايج آن در جدول س آورده شده است جدول r. نتايج آزمون بوت استرابٍ براى مسيرهاى غيرمستقيم.

\begin{tabular}{|c|c|c|c|c|c|c|}
\hline فاصله & حد بالا & حد يايين & نمونهَيرى مجدى & ملاكير & ميانجير & ميشغير \\
\hline.$/ 90$ & 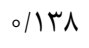 & $-\circ / \circ \circ \Delta$ & ra。 & كيفيت زندگى & تمايزيافتگى خود & سرمايه اجتماعى \\
\hline.$/ 90$ & $0 / 199$ & $-0 / 0 \circ \mathrm{V}$ & rdo & كيفيت زندگى & تمايزيافتخىى خود & هويت دينى \\
\hline
\end{tabular}

نتايـــج مندرج در جدول ب نشــان مىدهد كـــه حد يايين و حد بالاى مســيرهاى غيرمستقيم سرمايه اجتماعى به كيفيت زندگى؛ و هويت دينى به كيفيت زندكى از طريق تمايزيافتخى خود، صفر را در برنمى گيرند و اين حاكى از معنى دار بودن اين مســيرهاى غيرمستقيم است. بهعبارتديخر نقش ميانجى تمايزيافتتى خود در ارتباط بين سرمايه اجتماعى و هويت دينى با كيفيت زندگى مورد تأييد قرار گرفت.

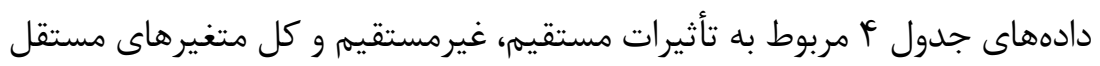
بر متغير وابسته كيفيت زندگى مىباشد. اثرات مستقيم همان همبستخَى ميان دو متغير است و اثرات غيرمستقيم، بيان كننده حاصل ضرب رابطههاى ميان متغير واسطه با هر يك ميك ميكي از دو متغير ييشبين و ملاك است.

جدول F. مجموع تأثيرهاى مستقيم و غير مستقيم متغيرهاى پيش بين بر متغير ملاك

\begin{tabular}{|c|c|c|c|}
\hline تأثير كل & تأثير غير مستقيم & تأثير مستقيم & متغير هاى بيشبين \\
\hline.$/ 09$ & $0 / 49$ & o/QT" & هويت دينى \\
\hline.$/ 91$ & $0 / \pi 1$ & $\circ / \Delta \varphi^{* *}$ & سر مايه اجتماعى \\
\hline $0 / 90$ & -- & $0 / 90^{* * w^{\circ}}$ & تمايزيافتتى خود \\
\hline
\end{tabular}


جدول f مقادير ضرايب مستقيم و غيرمستقيم را به سمت متغيرهاى ملاك نشان مى دهد. ضرايب مستقيم متغيرهاى هويت دينى، سرمايه اجتماعى و تمايزيافتخى خود

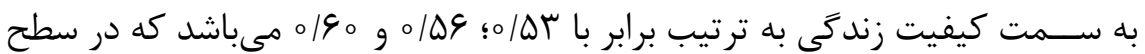
آلفاى | 1 /ه معنادار اســت. از ســوى ديخر ضرايب غيرمستقيمم هويت دينى و سرمايه

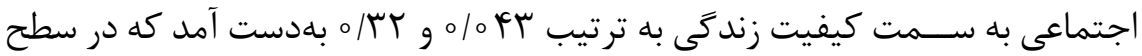

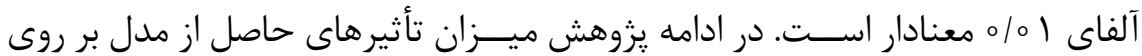
كيفيت زندگى بهدست آمد.

جدول ه. خلاصة مدل

\begin{tabular}{|c|c|c|c|c|}
\hline Sig & S.E & R.A & $\mathbf{R}^{r}$ & $\mathbf{R}$ \\
\hline 01001 & $0|f|$ & -/AV & $0 / T / 1$ & $0 / 4 \& V$ \\
\hline
\end{tabular}

نتايج جدول ه نشــان مى دهد كه مدل ترسيهم شـده قادر به تبيين / إ درصد از تغييرات كيفيت زندگى است. منظور اين است كه مجموع متغيرهاى ييشبين كه شامل هويت دينى و ســرمايه اجتماعى مىباشـــد از طريق تمايزيافتخًى خود، تا با بر دصد بر تغييرات كيفيت زندگى مؤثرند. بهعبارت ديخر اين مدل نشان مى دهد كه علاوه بر تأثير مســتقيهم هر يكى از متغيرهاى بيشبين بر كيفيت زندگى، تمايزيافتنى خود نيز باعث

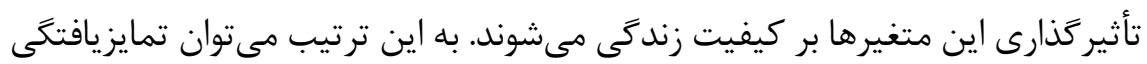
خود را عامل رابطه هر يك از متغيرهاى ييش بين با كيفيت زندگى دانست.

\section{بحث و نتيجل}

اين يزوهش با هدف تعيين رابطهُ بين هويت دينى و ســـرمائُ اجتماعى با كيفيت زندگى با آزمون نقش واسطهاى تمايزيافتخى خود در دانشجويان دانشعاه اروميه انجام كرديد. از نتايج اين يزوهش، رابطه مثبت و معنادارى بود كه بين هويت دينى و كيفيت زندكَى بهدسـت مستقيمم و غيرمستقيهم بهدسـت آمد؛ يعنى هراندازه هويت دينى در دانشجويان افزايش ريدا كند كيفيت زندگى آنان نيز بهبود مىيابد بهطورى كه مىتوان 
گفت امروزه بسيارى از فيلسوفان، جامعهشناسان و روانشناسان رويكرد كاركردگرايانه بـــهـ ديــن دارند و از آثار و نتايج التزام نظرى و عملى بـــهـ دين در حوزه نيازهاى روانى و نيازهاى اجتماعى كفتو گو مى كنند. اين در حالى اســت كه مكتب اســلام يكى از مهمترين رســالتهاى ييامبران الهى به ويزه يـامبر اسلام(ص) بهبود كيفيت زندكى

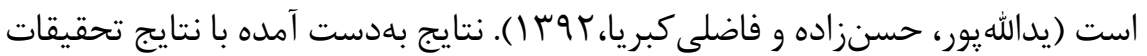
anter \& Siegel(2009) Gal Lim and Yi (2009)

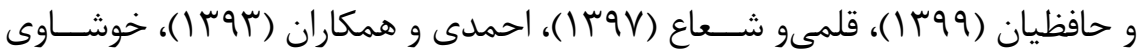

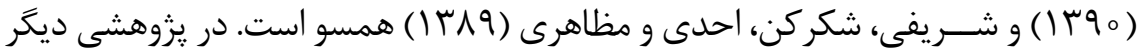

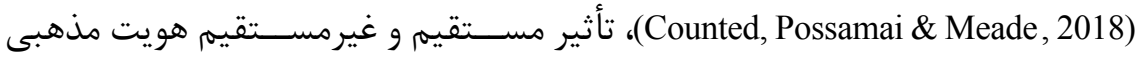
بر كيفيت زندگى را مورد تأييد قرار داده اسـت. خواجه نورى و همكاران (هوس|) نيز نشــان دادند تقويت عوامل مذهبى، باورها، عقايد افراد و هويت دينى افرد جامعه تأثير بهســزايـى بر بهبود ســلامت روانى، اجتماعى و جسمانى و در كل كيفيت زندكى افراد دارد. در تبييــن نتايج مىتوان كفت يايههاى دينــى و مذهبى يكى از عناصر قوى در

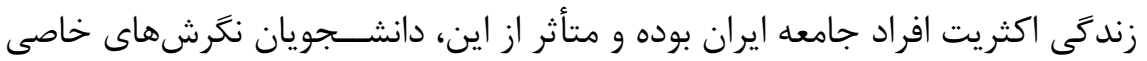

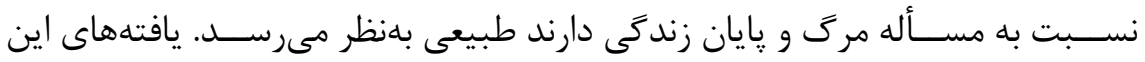
تحقيــق، با رويكردهاى نظرى، از قبيل نظريـــهـ دوركيهم مبنى بر اين كه فايده بىنهايت ارزشمند مراسم و مناسك دينى براى هر زروه اين است كه ييامدهاى مخرب اضطراب و شكســت و ناكامى را، كه همةٔ افراد و جوامع در معرض آن هســتند، كاهش مى دهد و در ييروانش احســاس خوشــى، سعادت و خوشــبـتـى اجتماعى را بهوجود مى آورد كه از ايـن نظريســـه مى توان استنباط كرد بالا بردن هويتى دينى دانشجويان مى تواند ييامدهاى مفيد و مثبتـى براى فــــرد در زنــــــى داشى داشته باشد كه باعث افزايش سطح كيفيت زندگى آنان شود. همجنين در بخش ديخرى از يافتهها حاكى از رابطه مثبت و معنادار بين ســـرمايه

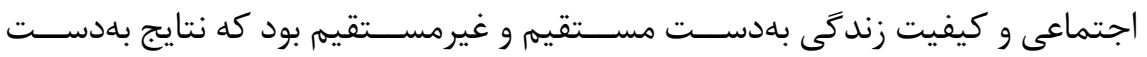

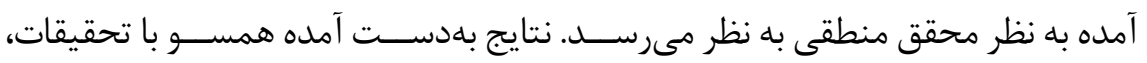

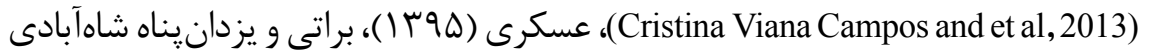

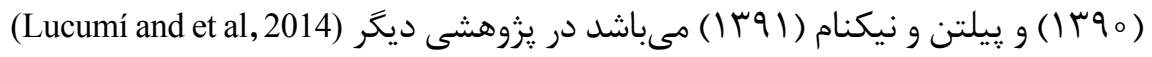


نشـــان دادند شاخصهاى سرمايةٔ اجتماعى بهصورت مستقيمى و مثبت با ابعاد فيزيكى و روانى كيفيت زندگى مرتبط با ســلامتى مرتبط بوده اســت. لقمان و همكاران ( نشــان دادند ارتباط معنى دار ميان ابعاد متغير سرمائُ اجتماعى و كيفيت زندگى وجود مرد

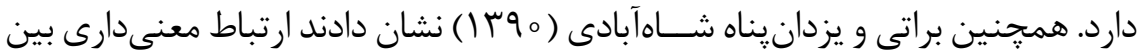
سرمائُ اجتماعى و كيفيت زندگى وجود دارد كه در تائيد يافتههاى اين يزوهش هستند. در تبيين نتايج بهدست آمده مى توان به ديدگاه اتكينسون، نولن هوكسما، بم، هيلغارد و اتكينسون (191|) اشاره نمود كه معتقدند سازگًارى با خود و محيط براى هر موجودى يك ضرورت حياتى بلشمار مىرود. تلاش روزمره همهٔ آدميان نيز عموماً بر محور همين ســاز Fارى دور مىزند. روانشناسان نيز بهطور معمول سازعارى با محيط را مورد توجه قرار دادهاند و ويزگ

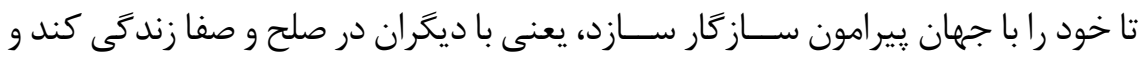
جايگاهى در جامعه براى خود بهدست آورد، كه در نهايت منجر به بهبود كيفيت زندگى مى شود. از ديكر نتايج اين يزوهش، ضرايب استاندارد مسيرها نشان دادند نقش ميانجى تمايزيافتكى خود در ارتباط بين ســرمايه اجتماعى و هويسـت دينى با كيفيت زندگَى مورد تأييد قرار گرفت.

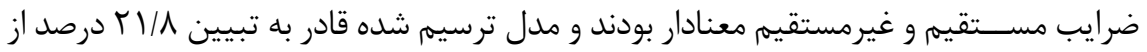
تغييرات كيفيت زندكى است و علاوه بر تأثير مستقيم هر يك از متغيرهاى پيشبين برمين بر كيفيت

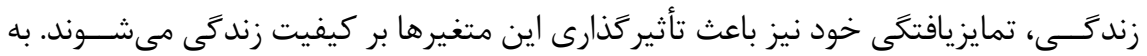
اين ترتيب ميى تــوان تمايزيافتكى خود را عامل رابطه هر يك از متغيرهاى ريش بيث با كيفيت زندگى دانســت، بدين معنى كه هر جه فرد، خود تمايزيافته تر باشد، كيفيت زندگى بالاترى را تجربه خواهد كرد و بالعكس.كه منطبق با ديد مىباشد كه معتقد است افراد تمايزيافته با اين ويزگگىها مشخص مىشوند الف) ممكن اســت عواطف منفى شديدى را تجربه كنـند. اما توســط اين عواطف تحليل نمىروند و واكنش اين دســــه افراد كنترل شــده اسـتـ همجنـين زمانى كه تجربههاى درونى يا تعاملات بين فردى بســـيار تنشزا باشـــ، افراد تمايزيافته لزومى احساس نمى كنـند كه از لحاظ عاطفى از ديخران جدا شـــوند. اين گَونه افراد از هويتى محكمم برخوردارند. ايــن يافته با نتايــــ تحقيقــات (Gabelman, 2012)، (Likcani, 2013)، كاظميان مقدم و 


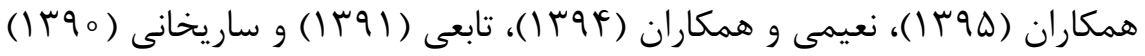
همسو است.

در تبييــن ايــنـن يافته مى توان كفت به نظريه بوئن اشــاره نمود كـــهـ بيان مى دارد،

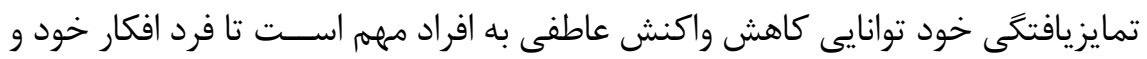
عقايدش را بدون توجه به فشارهاى اجتماعى بيان كند (YooYa, 2007).

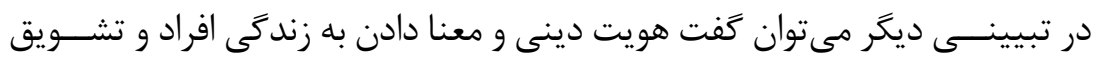

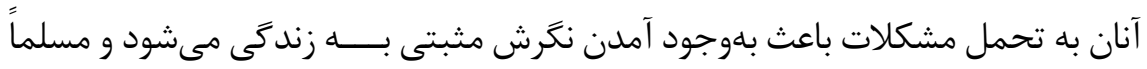

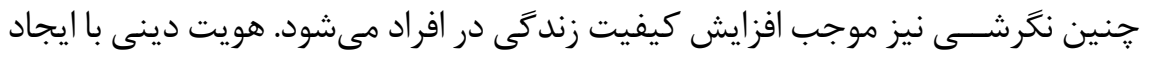

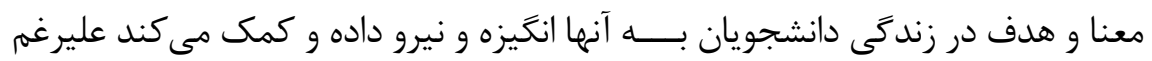

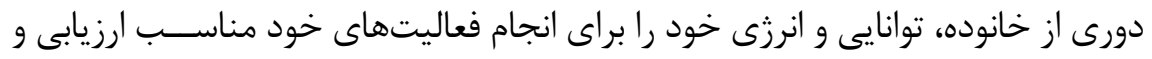

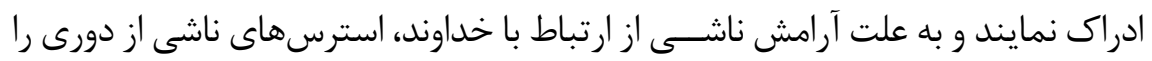

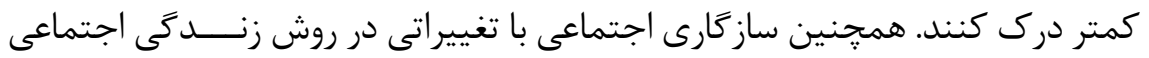

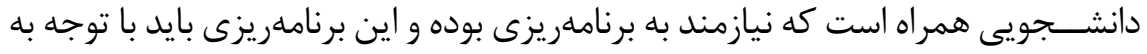

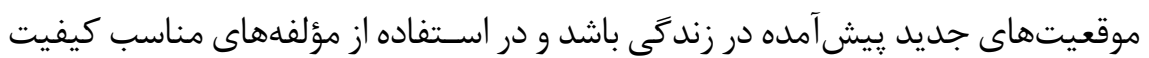

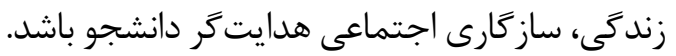

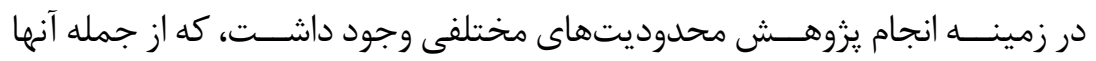

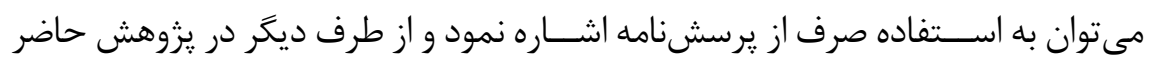

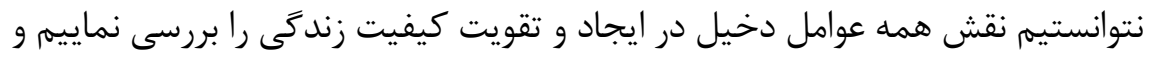

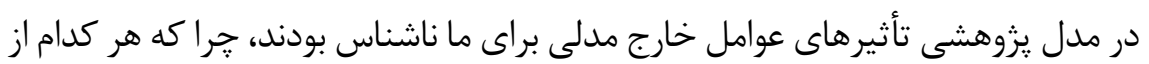

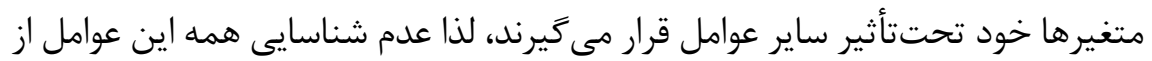
محدوديتهاى اصلى يزوهش بودند.

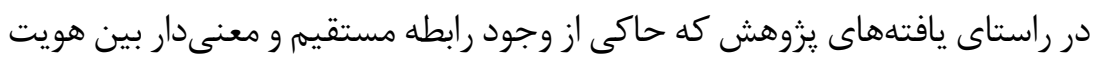

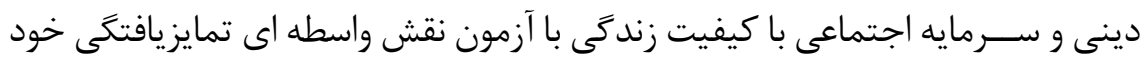

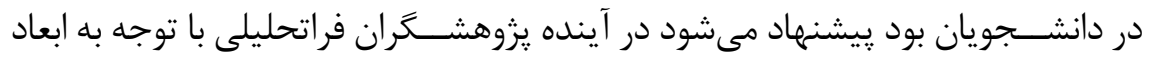

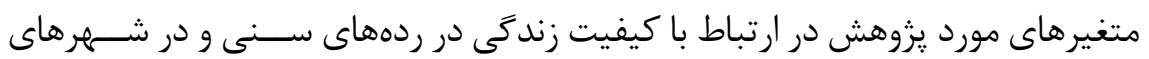

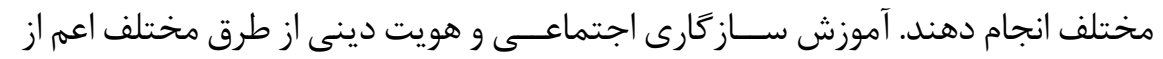

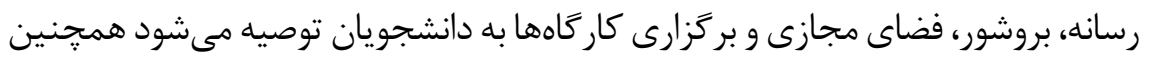


با عنايت به اينكه تركيب دانشــجويان در دانشخاهها متفاوت است يـيشهناد نقش بومى

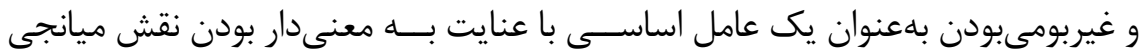
تمايزيافتخى خود مد نظر يزوهشَران آتى قرار گيرد.

\section{تشكّر و قدردانى}

بدينوسيله از دانشجويان دانشخاه اروميه كه در انجام اين تحقيق همكارى لازم را با محققين داشتند، كمال تشكّر و قدردانى را داريم. 


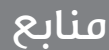

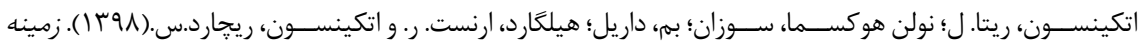

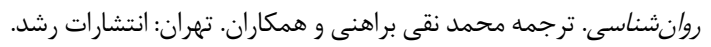

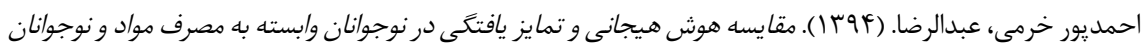

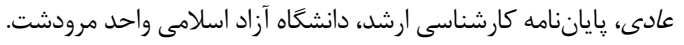

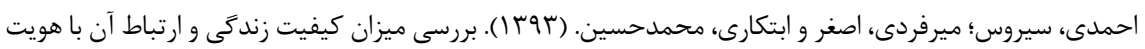

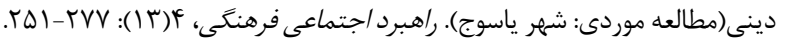

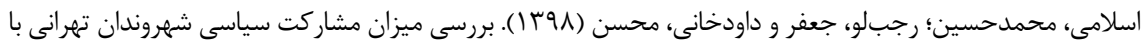

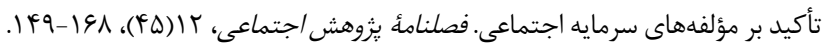

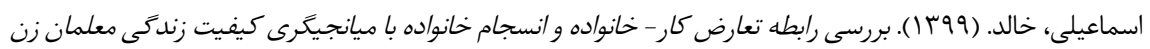

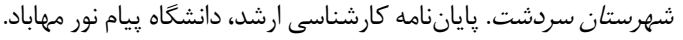

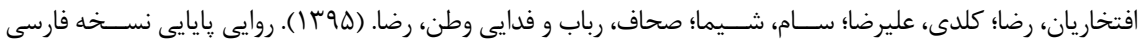

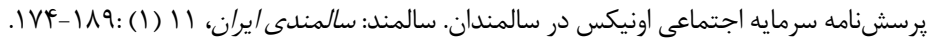

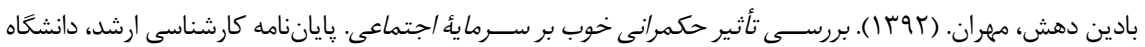

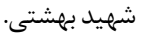

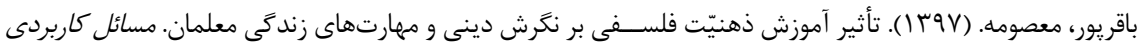
[Doi: qaiie.3, 2, 7/10, 29252]

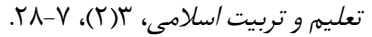

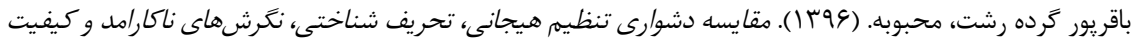

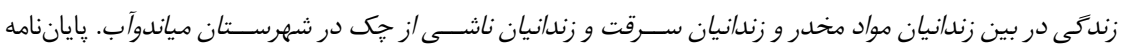
كارشناسى ارشد، دانشكاه آزاد اسلامى اروميه.

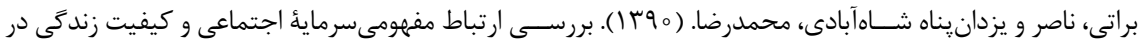

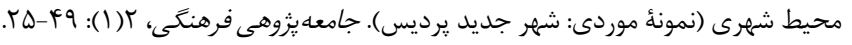

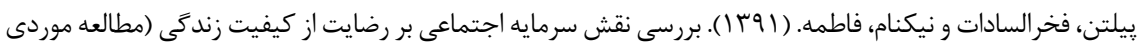

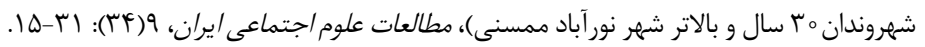

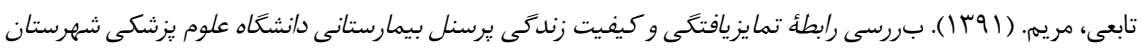
كاشان در سال ه9. يايان نامه كارشناسى ارشد، دانشكاه الزهرا.

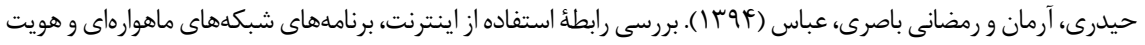

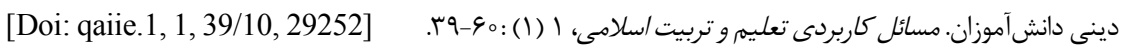

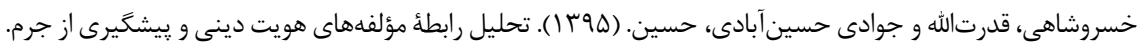

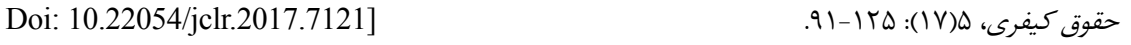

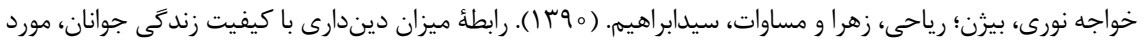

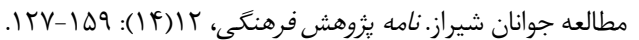

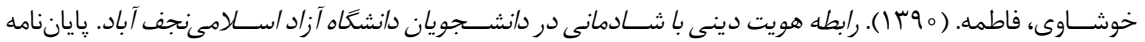
كارشناسى ارشد، دانشكاه شهيد بهشتى تهران.

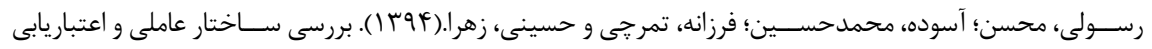

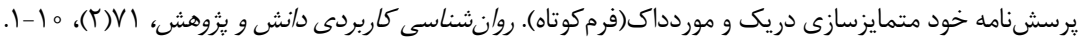

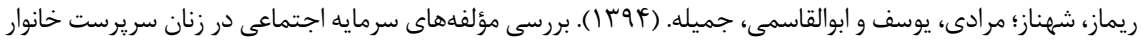

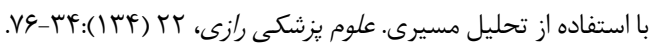




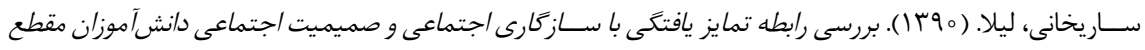

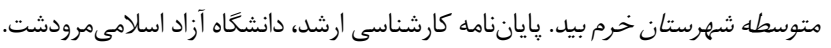

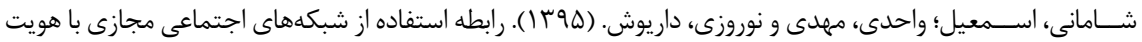

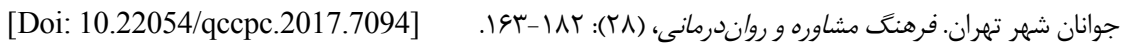

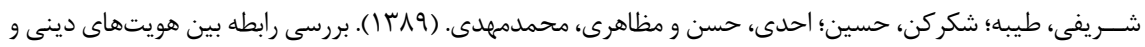

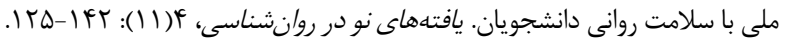

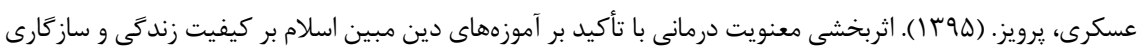

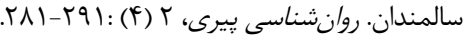

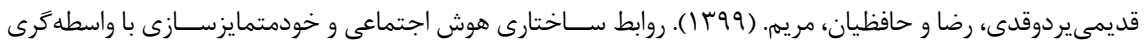

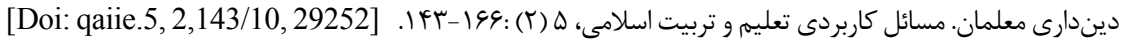

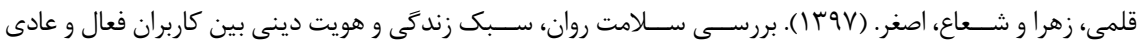

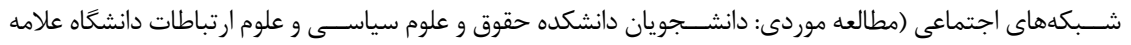

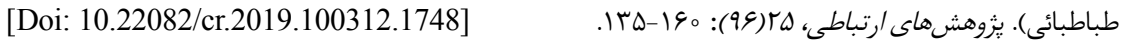

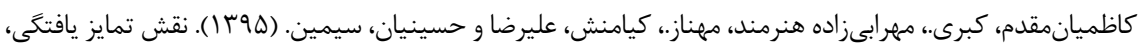

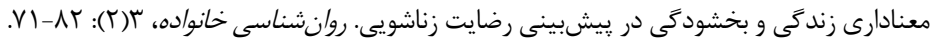

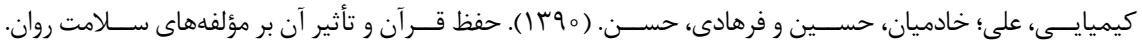

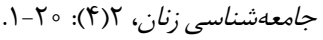

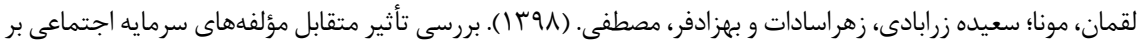

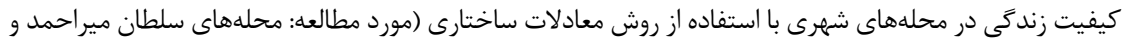
[Doi: 10/22052/1, 15,217]

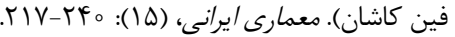

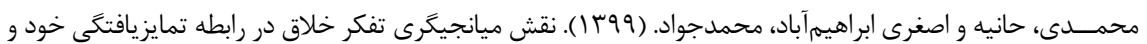

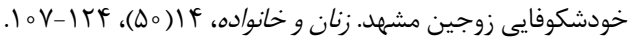

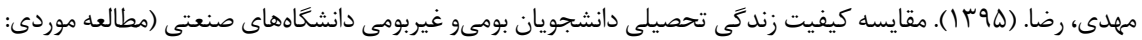

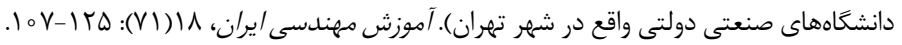
[Doi:10/22047/IJEE.2016, 31966]

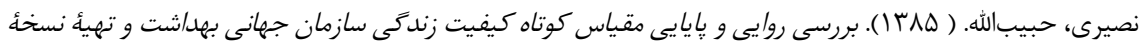

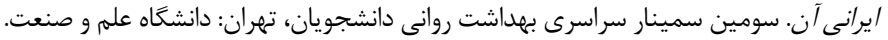

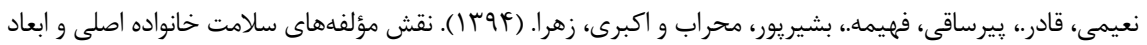

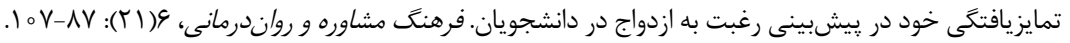
[Doi: 10.22054/QCCPC.2015.4190]

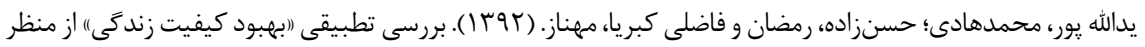

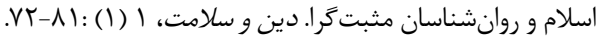

يوسفى فريده و صفرىهاجر. (1) (1). بررسى تأثير هوش عاطفى بر كيفيت زندگى و ابعاد آن در گروهى از دانشجويان [Doi: 10.22051/PSY.2009.1615]

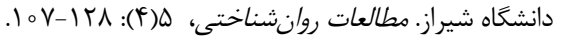




\section{REFERENCES}

Bandura, A. (2008). An agentic perspective on positive psychology. In Lopez SJ, (ed.), Positive psychology: Exploring the best in people. Westport, CT: Greenwood Publishing Company.

Baranci, \& Vidal, T.a. A. (2007). The measurement of teacher motivation: Cross-cultural and gender comparisons. Paper presented at the Annual meeting of the society for cross-cultural research (99th, New Orleans).

Bowen, M. (1978). Family therapy in clinical practice. New York: Jason Aronson.

Chien, W.T, Yick, S. (2016). An Investigation of Nurses' Job Satisfaction in a Private Hospital and Its Correlates. Open Nurs J, 10: 99-112. [Doi: 10.2174/1874434601610010099].

Counted, V., Possamai, A. \& Meade, T. (2018). Relational spirituality and quality of life 2007 to 2017: an integrative research review. Health and Quality of Life Outcomes, 16(1), 75-93. [Doi. org/10.1186/s12955-018-0895-x]

Cristina Viana Campos, A., Marques Borges, C. Rodrigues Leles, C. Dutra Lucas, S. and Ferreira, E. (2013). Social capital and quality of life in adolescent apprentices in Brazil: An exploratory study. Health, 5 (6), 973-980. [10.4236/health.2013.56128].

Gabelman, E. (2012). The effects of locus of control and differentiation of self on relationship satisfaction. Doctoral dissertation, The Ohio State University.

Galanter. M., \& Siegel, C. (2009). Training manual for spirituality discussion groups for mental health with focus on cultural competency center. New York: Mc Graw- Hill.

George, I. N. \& Ukpong, D. E. (2012). Adolescents' Sex Differential Social Adjustment Problems and Academic Performance of Junior Secondary School Students in Uyo Metropolitan City. International Journal of Business and Social Science, 3(19), 245-251.

Grootaert, C., Narayan, D., Jones, VN. And Woolcock, M. (2003). Measuring Social Capital: An Integrated Questionnaire. Whashington DC: Virginia, World Bank.

Hunt, C., Zahid, Sh., Ennis, N., Michalak, A., Masanic, Ch., Vaidyanath, Ch., Bhalerao, Sh., Cusimano, M. D. \& Baker, A. (2019). Quality of life measures in older adults after traumatic brain injury: a systematic review. Quality of Life Research; 28(12), 3137-3151. [Doi.org/10.1007/ s11136-019-02297-4].

Kwak, C., Chung, BY. Xu, Y. and Eun-Jung, C. (2010). Relationship of job satisfaction with perceived organizational support and quality of care among South Korean nurses: a questionnaire survey. Int J Nurs Stud, 47(10), 1292-1298. [Doi: 10.1016/j.jpnurstu.2010.02.014.].

Lex, H., Ginsburg, Y., F.sitzmann, A., Grayhack, C., F.maixner, D., J.mickey, B. (2018). Quality of life across domains among andividuals with treatment-resistant depression. Journal of affective disorders, 243, 401-407. [Doi: 10.1016/j.jad.2018.09.062 ].

Likcani, A. (2013). Differentiation and intimate partner violence. Dissertation for Doctor of Philosophy, Kansas State University.

Lim J. \& J. Yi (2009). The effect of religiosity, sprituality and social support on quality of life: A comprison between Korean American and Korean breast and gynecologic cancer survivors. Oncology Nursing Forum, 36(6), 699-708. [Doi: 10.1188/09].

Lucumi, I.D., Gomez, L.F.Brownson, R. and Parra, D. (2014). Social Capital, Socioeconomic Status, and Health-Related Quality of Life among Older Adults in Bogotá (Colombia). Journal of 
Aging and Health, 27(4), 730-750[Doi.org/10.3390/ijerph14030282].

McCullough, M., Pargament, K., \& Thorensen, C. (2009). Forgiveness: Theory, research, and practice. New York, NY: Guilford Press.

Min, S.K., Kim, K.I., Lee, C.I., et al. (2006). Development of the Korean versions of WHO quality of life scale and WHOQOLBREF. Qual Life Res, 1, 593-600.

Nowak, P. F., Boz ek, A. \& Blukacz, M. (2019). Physical activity, sedentary behavior, and quality of life among university students. Hindawi BioMed Research International, Volume 2019, Article ID 9791281,1-10.

Peleg, O. \& Messerschmidt- Grandi, C. (2018). Differentiation of self and trait anxiety: A crosscultural perspective. International Journal of Psychology, 54(6), 816-827. [Doi: 10.1002/ ijop.12535].

Rajagopal, D., Mackenzie, E., Bailey, C., \& Lavizzo-Mourey, R. (2002). The effectiveness of a spiritually-based intervention to alleviate subsyndromal anxiety and minor depression among older adults. Journal Religious Health, 41(2), 153-166. [Doi.org/10.1023/A:1015854226937].

Skevington, S.M., Lotfy, M. and O'Connell, K.A. (2004). The World Health Organization's WHOQOL-BREF quality of life assessment: psychometric properties and results of the international field trial. A report from the WHOQOL group. Qual Life Res, 13, 299-310. [Doi: 10.1023/B:QURE.0000018486.91360.00].

Skowron, E. A., \& Friedlander, M. L. (1998). The differentiation of self inventory: development and initial validation. Journal of Counseling Psychology, 54, 534-552. [Doi:10.1037/0022006X.54.3.395].

World Health Organization. (1998). Health promotion glossary. Geneva: Switzerland: author.

YooYa, Y. (2007).The relationship among the family functioning self-differentiation and junior high school student's irrational believes. Journal of Social psychology, 73, 223-34.

Zeegers, MAJ., Colonnesi, C., Stams, G.-JJM. \& Meins, E. (2017). Mind matters: A meta-analysis on parental metallization and sensitivity as predictors of infant-parent attachment. Psycholog Bull, 143(12), 1245-1272. [Doi: 10.1037/bul0000114]. 